\title{
IAMJ
}

INTERNATIONAL AYURVEDIC MEDICAL JOURNAL

Review Article

ISSN: 2320-5091

Impact Factor: 6.719

\section{REVIEW ON GERIATRICS THROUGH AYURVEDA}

\section{Dinesh Todkari}

Reader, Department of Samhita Siddhant, Government Ayurveda College, Vadodara, Gujarat, India

Corresponding Author: dineshtodkari@gmail.com

https://doi.org/10.46607/iamj.3309012021

(Published online: January 2021)

Open Access

(C) International Ayurvedic Medical Journal, India 2021

Article Received:26/12/2020 - Peer Reviewed:02/01/2021 - Accepted for Publication:06/01/2021

\section{Check for updates}

\begin{abstract}
In Ayurveda human life is classified in 3 states like Balyavastha, Tarunyavastha and Vardhakyavastha. Old age is supposed to be the most sensitive phase of life and needs utmost comfort and care. Today $8.5 \%$ of people worldwide are aged above 65 and over. According to 2016 report by the ministry for statistics and programme implementation, India has 103.9 million elderly, people above age 60 , about $8.5 \%$ of the population. This projected growth in the older population has the potential to place significant burdens on healthcare and support services. Aims and Objectives: To study the concept of Jara and to explore the preventive and possible treatment through Ayurveda. Materials and Methods: Classical texts of Ayurveda with respect to Jara and previous research work on ageing was studied, compiled, analyzed and presented in a systemic manner. Discussion: In Ashtang Ayurveda Jarachikitsa is considered as an independent separate branch which shows its importance. In Ayurveda the branch which deals with geriatric disorders is known as rejuvenating therapy (Rasayanchikitsa). Conclusion: Ayurveda is the science of life and longevity which has potential of preventing and curing geriatric diseases. Multi-dimensional approach of Ayurveda in prevention of early ageing and curing disorders of the elderly may provide some new hope. Present review work throws light on measures of geriatrics care through Ayurveda.
\end{abstract}

Keywords: Ayurveda, Elderly diseases, Preventive management, Rasayana

\section{INTRODUCTION}

Geriatrics is the science that deals with the study of diseases and their management particularly to elderly.
Aging is a physiological process that starts from birth, continues throughout life and ends with death. Re- 
search has led to a number of theories being proposed that may explain the ageing process but simply ageing is a common occurrence among most living things and is a permanent gradual physiological cellular decay ${ }^{[1]}$. Due to demographic transition in India, the elderly population is expected to rise up to $12 \%$ of the total population by $2025^{[2]}$. At least $65 \%$ of India's old population live in rural areas and are illiterate and economically dependent ${ }^{[3]}$. Thus, there is a need to address the medical and socio-economic problems of this vulnerable group and promote healthy ageing ${ }^{[4]}$. The aim of the present review article is to illuminate geriatric problems and their treatment methods through Ayurveda.

As per Charaka need of longevity of life is desire of every individual hence elaborated Dirgamjeevitiyamadhyay (chapter on longevity of life) in the beginning of their text Charaka samhita.

A person who takes suitable diet and practices selfcontrol lives full span of 100 years without illness. Stages of life as described in Ayurveda is as follows ${ }^{[5]}$ 1. Balyavastha (Childhood), which extends up to age 16 years.
2. Tarunyavastha (Adult age), which extends after age 16 to 60 years.

3. Vriddhavastha (old age), wherein after 60 to 100 yrs the body elements, sense organs, strength, energy, manhood, velour, memory, understanding, speech and discrimination begin to decay.

\section{Types of Jara}

As per Ayurveda, Kalajand Akalajjara may be considered as types of Jara. KalajaJara is considered as Swabhavikavyadhi, which cannot be prevented by medicines whereas Akalajajara i.e. premature ageing process can be prevented by adopting regular Panchakarma (body purificatory methods) and intake of Rasayana drugs.

Decade wise Stages of ageing and its impacts as per Ayurveda ${ }^{[6]}$

Scholars of latter stages like Vagbhata and Sharangdhara has described the 10-Phasic sequential biological changes taking place during $1^{\text {st }}$ to $10^{\text {th }}$ decades of life which may be restored up to the workable extent by adopting age specific Rasayanas (Rejuvenation).

Table 1: Age wise inherent bio losses

\begin{tabular}{|c|c|c|c|}
\hline Ageing Decades & \multicolumn{3}{|c|}{ Inherent Biolosses } \\
\hline $0-10$ & Balya & - & Corpulence/strong \\
\hline $11-20$ & Vriddhi & - & Growth/elongation \\
\hline $21-30$ & Chhabi & - & Lusture \\
\hline $31-40$ & Medha & - & Intellect/comprehension \\
\hline $41-50$ & Twaka & - & Skin appearance \\
\hline $51-60$ & Drishti & - & Vision \\
\hline $61-70$ & Shukra & - & Virility \\
\hline $71-80$ & Vikrama & - & Physical Strength \\
\hline $81-90$ & Buddhi & - & Thinking \\
\hline $91-100$ & Karmendriya & - & locomotion \\
\hline
\end{tabular}

\section{Health related old age Problems}

As the age progresses the number of health-related disorders increases. These health problems may be classified into different categories such as physiological, pathological, psychological, socio economical etc.

\section{Physiological Problems}

These are normally occurring and are due to aging process which results in disabilities. For instance, senile cataract, glaucoma, nerve deafness, wrinkles on skin, changes in mental outlook. 


\section{Pathological Problems}

Table 2: System wise diseases

\begin{tabular}{|l|l|}
\hline System/Channel & Diseases \\
\hline Blood related & Hypertension, Myocardial Infarction, Stroke \\
\hline Bone related & Arthritis, Osteoporosis, Gout \\
\hline Eye related & Cataract, Retinopathy \\
\hline Respiratory Diseases & Bronchitis, Asthma, Emphysema \\
\hline Genitourinary system & BEP, Dysuria, Nocturia, \\
\hline Nervous system & Alzheimer's disease, Parkinson's disease \\
\hline Others & Cancer, Diabetes mellitus, Obesity \\
\hline
\end{tabular}

\section{Socio economic Problems}

Indian old age people experience burden of communicable as well as non-communicable diseases besides impairment of special sensory functions like vision and hearing and other degenerative diseases. Low income of retirement, isolation because of death of family members, maladjustment with younger generation, worst geographical access and unaffordable treatment also lead to low use of health care especially among the elderly. They are also facing abuse in their families or in institutional settings. A study in Chennai among 400 community-dwelling elderly aged 65 years and above found the prevalence rate of mistreatment to be $14 \%$. Chronic verbal abuse was the most common followed by financial abuse, physical abuse and neglect. ${ }^{[7]}$

\section{Material and Methods}

This is literary review research study done for finding out all possible scientific information on jara(ageing).

Source of Data: Ayurveda classical texts like Charaka Samhita, Sushrut Samhita, Sharangdhar Samhita along with available commentaries and published articles in journals, Modern textbooks and other material available online have been thoroughly studied, analyzed and described in efficient manner.

State-wise Demographic Elderly Status in India

The age wise distribution of Indian population from 2009 to 2019. In 2019, about 26.62 percent of the Indian population fell into the 0-14-year category, 67 percent into the 15-64 age group and 6.38 percent were over 65 years of age. On comparing 2001 and 2011 Population Census ${ }^{[8]}$ data, it was revealed that the average increase of elderly population among states is $1 \%$. State-wise data on elderly population reveals that Kerala had maximum proportion of elderly people in its population (12.6\%) followed by Goa (11.2 \%) and Tamil Nadu (10.4\%) as per Population Census. According to the state of world population 2019 report by the United Nations population fund (UNPFA), India's population in 2019 stood at 1.36 billion and six per cent of India's population was of the age 65 and above. This may be due to the lifestyle and better medical facilities in respective states.

Figure 1: Percentage of the elderly in the total population of States/UTs

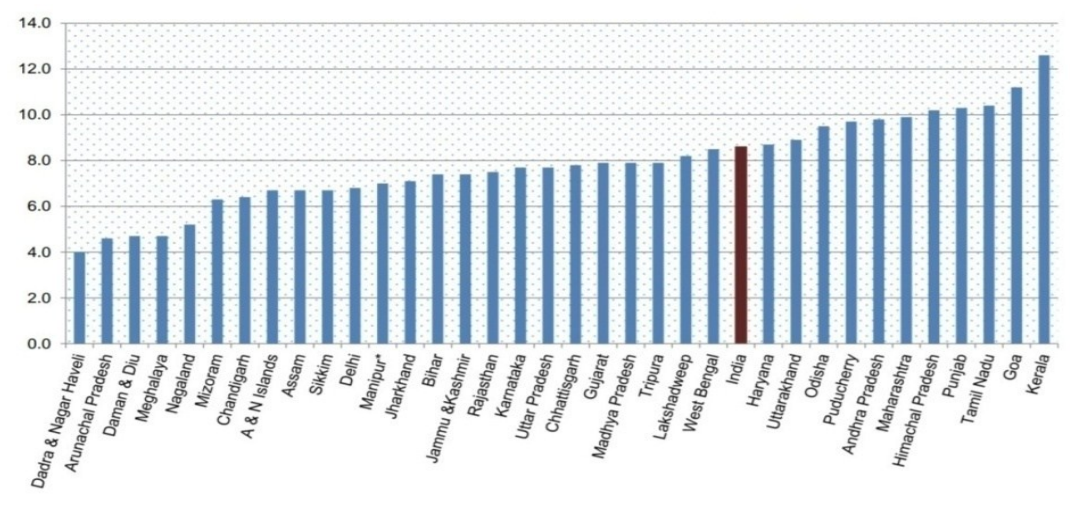


Source: Population Census 2011

Mortality and Morbidity Status of Elderly ${ }^{[9]}$

Morbidity

- Injuries: $3-5 \%$ fractures, $5-10 \%$ are soft tissue injuries.

- Long lies: 40-50\% unable to get up.

- Quality of life: fear of falling.

Mortality

- Sixth leading cause of death in elderly.

- $70 \%$ of all deaths due to fall occurring in $12 \%$ of the population age 65 years and older.

Preventive and curative methods in old age

As per Ayurveda principle Swasthasyaswasthyarakshanam can be achieved only by keeping dhatus in equilibrium state. For this Rasayanchikitsa (rejuvenating therapy) and Ahar (diet) is to be takenin proper manner particularly in old age. Special attention towards Jatharagni (digestive fire) is very important in old age. Doshanulomana (laxation) is also very important for achieving health.

Role of Rasayan Chikitsa in elderly

Rasayana is the branch of Ayurveda which includes a number of specialized methods aimed at prolonging life, preventing aging and diseases, eliminating degenerative processes and promoting health. Sushruta has described Rasayana as one, which delays ageing, increases the lifespan, promotes intellect, memory, and increases resistance to diseases ${ }^{[10]}$.

It is always better to take shodhan (Panchakarma) prior to rasayanchikitsa for better results of $\mathrm{ra}$ sayanchikitsa. Rasayana Therapy can be advocated at outdoor level (Vatatapika Rasayana) and with hospitalization also (KutipraveshikaRasayana) depending upon the need of patients.

Scientific evidence of some rasayankalpas and other proved single herbs

\section{- Multi-facetted protective role of Chya- wanprasha}

Chyawanprasha showed significant immunomodulatory activity (decrease in Ig G, C3 and C4 levels in patients of recurrent cough and cold), cytoprotective action (cancer patients receiving radiation therapy showed a protective role against radiation induced tissue damage) and Genoprotective action (significant reduction in Mitotic Index (MI) and Chromosomal Aberrations (CA) ${ }^{[11]}$

- Immunomodulator and Anti-tumor action of Ashwagandha

Ashwagandha acts as an immunomodulator and hence can enhance life span of cancer patients, where lowered immunity states of the patient are the cause of concern. The results suggest its use as anti-tumor ${ }^{[12]}$ and immune modulator agent ${ }^{[13]}$

- Ashwagandha (Withaniasomnifera) and aging Statistically significant increase in Haemoglobin, RBC count, hair melanin \& seated stature and decrease in serum cholesterol and ESR is found by using Ashwagandha powder in old age. ${ }^{[14]}$

- Improvement in Quality of vision by Palash (Butea monosperma)

Butea monosperma root distillate in the management of age related immature cataract: The root distillate drops of Butea monosperma developed as per I.P Standards has shown significant improvement in visual acuity and quality of vision (disturbance in vision viz haziness and diplopia) in the subjects of age related immature cataract $(\mathrm{n}=52)^{[15]}$.

- Shallaki (Boswelia serrata) in Rheumatoid arthritis

ShallakiVs Diclofenac sodium: $600 \mathrm{mg}$ of Shallaki thrice in a day and $50 \mathrm{mg}$. of Diclofenac Sodium thrice in a day was given in experimental and control groups respectively for four weeks. Efficacy of Shallaki was found to be comparable to that of Diclofenac Sodium in the patients of RA, who demonstrated predisposition for gastric intolerance with antiinflammatory medication. ${ }^{[16]}$

- Guggulu (Commiphora wightii) in Hyperlipidaemia

Guggulu (Commiphorawightii) Vs Placebo: Cardinal clinical manifestations of disease like precordial pain and dyspnoea were relieved in in most of the cases in a clinical study tried with Guggulu in the dose of 8 gm/day. Substantial fall in lipid fractions like cholesterol $27 \%$, triglycerides $36 \%$, phospholipids $20 \%$ and free fatty acids $37 \%$ indicated the possibility of regression of atherosclerosis. The reversal of ECG 
changes substantiated the anti-ischemic effect of the drug in the treatment of ischemic heart diseases. ${ }^{[17]}$

- Guduchi (Tinosporacordifolia) as immunomodulatory agent

Clinical studies of Guduchi have shown significant efficacy in the cases of obstructive jaundice. ${ }^{[18]}$

- Management of hemiplegia by Panchakarma:

Comparative study of 744 hemiplegics revealed that 552 subjects who received Panchakarma therapy showed significant recovery from illness, with improvement in motor functions and quality of life in comparison to subjects who received Shamana therapy (palliative therapy) alone ${ }^{[19]}$.

- Kantakari (Solanum xanthocarpum) in TamakaSwasa (Bronchial asthma)

In a clinical trial on 44 patients of Bronchial asthma, decoction of Kantakari in doses of $60-200 \mathrm{ml}$ daily with honey was given for a period of 15-20 days on an average. Out of 21 cases ofSleshmapradhanaTamakaswasa,70-75\% shown complete or significant response and out of 23 cases of VatapradhanaTamakshwasa 30\% showed complete response and in more than $50 \%$ cases significant reduction in intensity of dyspnoea and cough was observed. ${ }^{[20]}$

\section{Diet and Nutrition in geriatric care}

As per Ayurveda concepts, there is increase of Vaatdosha in old age. vishamagni (Irregular digestive fire) resembles with vaat, so to maintain Agni in old age one should have meals with respect to status or strength of Agni. In old age diet should be well balanced low in saturated fats, add calcium rich diet, add fruits and green leafy vegetables.

Diet plays prime role in process of premature ageing. The faulty dietary habits like Vishamashana, Adhyashana, Ajeernashana, Amla-Lavana Rasa atisevana can hasten the process of ageing at micro as well as macro cellular level resulting into premature ageing. Therefore, it is important to follow the good dietary pattern prescribed in Ayurveda classics so as to live young for a long time with healthy ageing and happy life. ${ }^{[21]}$

Behavioral and Ethical considerations (Sadvritta)in old age

Achar rasayan (Good conduct)

To prevent from psychosomatic disorders in old age one can adopt methods like Achar Rasayana ${ }^{[22]}$ mentioned in table below

Table 3: Achar Rasayana

\begin{tabular}{|l|l|}
\hline Achar Rasayan & Good Conduct \\
\hline Satyavadinam & True speaking \\
\hline Akrodham & Refrain from anger \\
\hline Nivruttammadyamaithunat & Refrain from alcohol and sexual acts \\
\hline Ahimsakamanayasam & One should be Nonviolent and avoid exertion \\
\hline Prashantam & One should be peaceful \\
\hline Japashauchparam & Always busy in chanting of god's name and cleanliness \\
\hline Dheeram & One should be Courageous \\
\hline Samajagaranaswapanam & One should sleep and get up at proper time \\
\hline Nityamkshiraghritashinam & Include milk and ghee in daily meals \\
\hline AdhyatmaPravanendriyam & Always inclined towards spirituality \\
\hline Dharmashastrparam & busy in reading religious books \\
\hline
\end{tabular}

Alcohol and elderly

It is linked to liver diseases, hypertension, stomach ulcers, heart disease, gout, depression and osteoporosis ${ }^{[23]}$. Sensitivity to the effect of alcohol is directly proportional to the age.

\section{DISCUSSION}

Though the risk of developing diseases increases with progressing age, but it is not an unavoidable result of aging. Prevention and treatment of health problems may help the elderly to improve quality of life and remain independent for their daily activities to some extent. Variety of single 
and compound Rasayana medicines possessing diversified actions like immuno-enhancement; free-radical scavenging, anti-depressant and nutritive effects are described in Ayurveda literature for their use in health promotion and curing diseases with betterment in the quality of life. $R a$ sayanchikitsa for old age is cost effective and affordable by all sections of people, well tolerated and has no adverse reactions. Non-pharmacological treatment like Aacharrasayan may be very useful in geriatric care to keep mental health stable. Lifestyle modulation (Swathavritta and Sadvritta) remains integral to the prevention of elderly problems.

\section{CONCLUSION}

Geriatric is such stage of life in which one has to face physical, psychological, socio-economic problems. Here in this paper honest attempt has been made to address the issues of old age to some extent. Multi-dimensional approach of Ayurveda in prevention of ageing and curing elderly disorders may provide some new hope. This research opens new windows for further study on group of drugs like Vayasthapanamahakashaya a Dashemani (group of ten drugs) having Rasayana properties which promotes overall nourishment of body tissues. Research may be conducted on each single drug or by taking collective measures such as dietetics, panchakarma, dinacharya-rutucharya, sadvrutta, yoga and other spiritual methods.

\section{REFERENCES}

1. Feltes, Bruno Cesar; de FariaPoloni, Joice; Bonatto, Diego, Yashin, A.I.; Jazwinski, S.M. (eds.), Development and Aging: Two Opposite but Complementary Phenomena, Interdisciplinary Topics in Gerontology, S. KARGER AG, 40,doi:10.1159/000364932, ISBN 978-3-318-02729-7; 2008, pp. 74-84.

2. Government of India, Operational Guidelines: National Programme for Health Care of the Elderly (NPHCE); 2016; New Delhi: Ministry of Health and Family Welfare.

3. Ingle $G$, Nath A. Geriatric health in India: Concerns and solutions; Indian J Community Med; 2008,33:2148.

4. Government of India: Morbidity, health care and the condition of the aged. 2006; National Sample Survey Organization $60^{\text {th }}$ round (January-June 2004).

5. Sushruta, Sushruta Samhita, Edited by KavirajAmbikadutta Shastri, Sutrasthana (35:34-36), Chaukhambha Sanskrit Sansthan, Varanasi, 2007, pg. 173-174.
6. Sharangdhar, Sharangadhara Samhita Tatwadipika, Hindi commentary by Bhishakvachaspati Pandit Durgadutta Shastri, Prathama khanda (6:19), Varanasi, Chaukhamba Vidyabhavan, 2002, Pg. 91.

7. Chokkanathan S, Lee AE. Elder-mistreatment in urban India: A community based study; 2005, J Elder Abuse Negl. 17:45-61.

8. Govt. of India. Elderly in India-Profile and Programs, Report by Central Statistics office, Ministry of Statistics and Programme Implementation;2016, www.mospi.gov.in.

9. Dey A B, Handbook of Geriatrics, first edition, Hyderabad, India; 2007, Paras medical publisher; Pg. 118.

10. Sushruta, Sushruta Samhita, Edited by Kaviraj Ambikadutta Shastri, Sutrasthana; edited with Ayurveda tatvasandipika Hindi Commentary, Sutra Sthana (1:8), pg. 4.chapter, Vedotpatti-adhayay, 2007, Chaukhambha Sanskrit Sansthan, Varanasi, reprint edition .

11. Brindavanam NB, Bhattacharya N, Katiyar CK, Narayana DBA Multi-facetted protective Role of Rasayana Therapy: A review of investigations on Chyawanprasa.; 2002, Ayurvedic Conference on Rasayana 2002, Rashtriya Ayurveda Vidyapeeth, India.

12. Singh SP, Singh DR, Gupta ML, Singh N, Kohli RP. An experimental evaluation of anti-tumor activity of Withaniasomnifera (Ashwagandha) and "Geriforte"; 1979, XI Annual Conf IPS Ind Jour Pharmacol. ;11(1):65.

13. Dixit KS, Agarwal AK, Seth PK, Singh N. World Congress on Biotech Dev Med Subs Plants \& Marine Origin. Lucknow (India): King George Medical College; Effect of Withaniasomnifera, Panex ginseng and Cannabis indica and radio ligand binding with neurohumoral in the CNS; 1995, p. 141.

14. Kuppurajanetal, Effect of Aswagandha (Withaniasomnifera) on the process of ageing in Human volunteers;1980, Journal of Research in Ayurveda and Siddha.1(2);247-58.

15. Srikanth N, Dua M, Bikshapathi TButea Monosperma root distillate eye drops (PalasaMoolaArka) in age related immature cataract: A clinical observation; 2006, J Res Ayurveda and Siddha 27: 12-23.

16. Bichile, LS et al., Double blind randomized controlled trial of Sallaki Vs Diclofenac in treatment of Rheumatoid arthritis, Select Research Papers on Evidence Based drugs in Ayurveda, 2000, Dept of ISM\&H, Ministry of Health, Government of India, New Delhi.

17. Govt of India, Clinical and Experimental trial of Guggulu (Medoroga).1989, CCRAS, New Delhi 
18. Dahanukar et al., Immunotherapy with Tinosporacordifolia: A new lead in the management of obstructive jaundice by Tinospora cordifolia,1993, Indian J Gastroenterol, $12-5$.

19. Central Council for Research in Ayurveda and Siddha Management of Hemiplegia by Panchakarma therapy. 1990, CCRAS, New Delhi.

20. J.P. Jain, A clinical trial of Kantakari (Solanum xanthocarpum) in cases of TamakaSwasa, Journal of Reserch in Ayurveda \& Siddha,1980, Vol. I No. 3PP 447-460.

21. Deole et al., A Cross Sectional Study On Dietetic Causative Factors Of Premature Ageing Described In Ayurveda, 2017, JREIM; XXIII (23) 31-37.

22. Agnivesha, Charak Samhita, Ayurveda Dipika commentary by Chakrapanidatta, reprint edition by Harishchandra Singh Kushwaha, Chikitsa Sthan, 2009, (1:4:30-35), Pg. 43 Part II. Chaukhambha Orientalia, Varanasi, India.

23. O'Connell H, Chin AV, Cunningham C, Lawlor B Alcohol use disorders in elderly people--redefining an age-old problem in old age, 2003, BMJ 327: 664-667.

\section{Source of Support: Nil \\ Conflict of Interest: None Declared}

How to cite this URL: Dinesh Todkari: Review on Geriatrics Through Ayurveda. International Ayurvedic Medical Journal \{online\} 2021 \{cited January, 2021\} Available from: http://www.iamj.in/posts/images/upload/205_211.pdf 